\title{
Natural and anthropogenic alterations of the soil affect body condition of the fossorial amphisbaenian Trogonophis wiegamnni in North Africa
}

\author{
José Martín ${ }^{\mathrm{a}, *}$, Pilar López ${ }^{\mathrm{a}}$, Eduardo Gutiérrez ${ }^{\mathrm{b}}$, Luis V. García ${ }^{\mathrm{b}}$ \\ a Departamento de Ecología Evolutiva, Museo Nacional de Ciencias Naturales, CSIC. 28006 Madrid, \\ Spain. E-mail address: Jose.Martin@mncn.csic.es (J. Martín)
}

${ }^{b}$ Departamento de Biogeoquímica, Ecología Vegetal y Microbiana, Instituto de Recursos Naturales y Agrobiología de Sevilla, CSIC, 41012 Sevilla, Spain

\begin{abstract}
Soil alteration is one of the major threats in arid environments, which can have serious consequences for soil biodiversity. However, the ecology of fossorial animals is poorly understood and their low conspicuousness may lead researchers and managers to overlook potential conservation problems. Amphisbaenians are fossorial reptiles and, because of their secretive habits, there is a chronic almost lack of data on their conservation state. Here, we examined the effects of diverse natural (salinization and seagulls influence) and anthropogenic factors (disturbance of the soil physical structure and lead contamination) that affect physical and chemical properties of the soil on body condition of Trogonophis wiegmanni amphisbaenians from the Chafarinas Islands, in North Africa. Results indicated that soil salinization and human induced mechanical disturbance and compaction of the soil affected negatively to body condition of amphisbaenians. In contrast, the increase in organic matter and heavy metals pollutants in the soil, either because of the seagull or anthropogenic influence, did not seem to affect body condition of amphisbaenians. We suggest potential management techniques to solve these problems and emphasize the need for periodic surveys of subterranean herpetofauna to prevent future conservation problems.
\end{abstract}

Keywords: Reptiles, Amphisbaenia, Soil degradation, Salinization, Seagull influences, Soil compaction 


\section{Introduction}

Soil alteration is one of the major threats in arid environments (Dregne, 1976; Zeppel et al., 2003), which can have serious consequences for soil biodiversity. However, compared to terrestrial epigeal animals, the fossorial fauna inhabiting underground environments has been little studied and their ecology is little understood (Copley, 2000). Soil biodiversity is considered to be an important factor in regulating the functioning of terrestrial ecosystems, but this importance is often not appreciated (Decaens et al., 2006), and the absence of concern about fossorial animals from conservationists is conspicuous (Wolters, 2001; Böhm et al., 2013). This may have unfortunate consequences for conservation planning, because fossorial species may be at particular risk from anthropogenic disturbance and local extinction of fossorial populations due to landscape and soil alterations may be occurring unnoticed (How and Shine, 1999; McKenzie et al., 2003; Zeppel et al., 2003; Measey, 2006; Measey et al., 2009).

Moreover, most studies deal with soil invertebrate ecology, while fossorial vertebrates are largely overlooked (Measey, 2006; Böhm et al., 2013). Among them, several groups of reptiles and amphibians, as much as $20 \%$, nearly 3,000 species of the world's herpetofauna, are fossorial (Measey, 2006), and their ecology and conservation status is much less well understood than that of their epigeal relatives (Böhm et al., 2013). Amphisbaenians are one of the prominent groups of fossorial reptiles with important morphological and functional adaptations to the underground life (e.g. reduced vision, elongated body, and loss of limbs in most species) (Gans, 1978, 2005) and a suite of original responses to ecological demands (e.g. Papenfuss, 1982; Martín et al., 1990, 1991; López et al., 1998; Webb et al., 2000). However, because of the fossorial secretive habits of amphisbaenians, there is very little information on the ecological requirements of most species, and there is a chronic almost lack of data on their potential conservation problems (Böhm et al., 2013). Most amphisbaenians live in tropical wet areas, but also in arid regions there are a few species, such as the Checkerboard Worm Lizard, Trogonophis wiegmanni, a representative of the family Trogonophidae inhabiting North Africa (Bons and Geniez, 1996; Gans, 2005). It lives buried in the soil and it is usually found thermoregulating or foraging under rocks (López et al., 2002; Civantos et al., 2003; Martín et al., 2011b,c, 2012, 2013a,b). It is listed as of 'Least Concern' by the IUCN in view of its wide distribution and "presumed" large population (Mateo et al., 2009). However, the potential threats to this species have not really been studied and are, 
therefore, not well known. We predicted that, given the fossorial habits, soil alterations should have a profound impact on health state and conservation of amphisbaenians.

In this paper, we examined diverse natural and anthropogenic factors that affect physical and chemical characteristics of soils used by a population of T. wiegmanni amphisbaenians from the Chafarinas Islands, in North Africa. We specifically considered the following potential threats identified in a preliminary survey (Martín et al., 2001a): two of natural origin (salinization and influence of seagulls on soil properties) and two of anthropogenic origin (disturbance of the soil physical structure and contamination by lead).

One of the threats of soil degradation in arid habitats is salinization (Zeppel et al., 2003; Rengasamy, 2006). Salinization can be caused by natural processes, such as mineral weathering or the gradual withdrawal of the sea, but it also may be induced by intense use of groundwater resources. Salts from the groundwater are raised by capillary action to the surface of the soil, decreasing soil water osmotic potential (Bressler et al., 1982). Therefore, water availability is much lower in saline soils, which may affect directly osmoregulation and cause dehydratation of amphisbaenians tissues (Schoemaker and Nagy, 1977). Thus, we predicted that more saline soils may affect negatively to amphisbaenians.

On the other hand, concentration of seagulls in nesting and resting areas also induces profound changes in soil chemical properties including eutrophication, salinization, acidification and nutrient imbalances (García et al., 2002a,b). Moreover, seabirds may be the main vectors moving heavy metals to soils (Headley, 1996; Otero, 1998; García et al., 2002a,b, 2007b), which can be then transferred to plants and soil invertebrates, and go up the food chain to reach high toxicological concentrations in vertebrate tissues (e.g. Márquez-Ferrando et al., 2009). We predicted that if there were actual differences in chemical properties of the soil in sites used by seagulls, these could affect negatively to amphisbaenians.

In addition to natural causes, urbanization by man has induced modifications of physical, chemical and biological properties of soils (Craul, 1992). Anthropic activities have led to profound modifications of the original soil horizons affecting their physical properties and the addition of organic residues and materials of domestic or industrial origin (Craul, 1992; Effland and Pouyat, 1997). These soil alterations may lead to increased compaction, restricted aeration and water drainage and the possible presence of contaminants, especially lead (Markus and McBratney, 2000). Anthropic soils are, however, often used by fossorial animals that live near 
human settlements. Thus, we predicted that if anthropogenic disturbance resulted in alteration of the physical properties of the soil and lead contamination, these changes may also affect negatively to amphisbaenians.

To assess how these potential threats to soil characteristics may affect amphisbaenians, we measured body condition of individual T. wiegmanni amphisbaenians that used these soils. Body condition is an important measure of the fitness of an animal, because it reflects the relative amount of energy stores (Green, 2001; Schulte-Hostedde et al., 2005), which can be allocated to maintenance, growth or reproduction (Perrin and Sibly, 1993; Heino and Kaitala, 1999; Madsen and Shine, 2002). Information on the condition of individuals in a population is necessary to predict potential reproductive output and changes in population size. Thus, a population with many animals in poor condition could indicate that individuals have a low reproductive potential and the population might be declining.

\section{Material and methods}

\subsection{Study area}

We conducted field work at the Chafarinas Islands (Spain), a small island archipelago located in the southwestern area of the Mediterranean Sea ( $\left.35^{\circ} 11^{\prime} \mathrm{N}, 2^{\circ} 25^{\prime} \mathrm{W}\right), 2.5$ nautical miles off the northern Moroccan coast (Ras el Ma, Morocco) and 27 miles to the east of the Spanish city of Melilla. It consists of three islands: Congreso (25.6 ha), Isabel II (15.1 ha) and Rey Francisco (13.9 ha). The islands present a dry, warm, Mediterranean climate, very influenced by dominant winds from the east and west. Vegetation is conditioned by the aridity of the climate (an average annual precipitation of $300 \mathrm{~mm}$ ), the high soil salinity, and the guano accumulation from numerous seabird colonies (in Congreso and Rey Francisco) (García et al., 2002a,b). Vegetation is dominated by woody bushes (Salsola, Suaeda, Lycium and Atriplex) adapted to salinity and drought (García et al., 2002a,b). Natural soils are poorly developed and immature and are characterized by a thin A horizon, rich in organic matter, which is underlain by the original volcanic rock (Clemente et al., 1999; García, 2005; García et al., 2007a). Only Isabel II Island is currently inhabited by a small population (less than 50 people). However, the islands supported a greater population until half of the 20th century, and many buildings (some in ruins) 
and paved streets cover $34 \%$ of the Isabel island surface, and $1 \%$ of surface in each of Rey and Congreso (García, 2005).

Two of the islands, Congreso and Rey, support nesting colonies of two species of seagulls; the Audouin's gull (Larus audouinii) (897 nests in Rey in 2011), a rare and protected Mediterranean seabird, and the widespread yellow-legged gull (L. cachinnans) (2250 nests in Rey and 3244 nests in Congreso in 2011), a Mediterranean seabird 'pest'”. The population of yellow-legged gull has increased considerably in the last years as in 1976 the figures were 300 nests in Rey and 600 nests in Congreso. There is also an important breeding colony in Congreso of Cory's shearwater (Calonectris diomedea) (400-500 nests in burrows or under rocks). The third island (Isabel) is inhabited by man and has had negligible seabird influence since 1848.

\subsection{Study animals and body condition}

We visited the study area during two weeks in March 2011. We walked haphazardly covering all the habitats and types of soils available in the three islands (Clemente et al., 1999; García, 2005), on days with favorable climatic conditions (warm sunny days) and between 07:00 and 18:00 (GMT), searching for amphisbaenians by lifting all stones found. We captured amphisbaenians by hand, gathered morphological measurements in situ and released them at their exact point of capture in less than 5 min. We determined sexes of adult amphisbaenians by examining cloacae (Martín et al., 2011c). For each individual we measured total length (TL; from the tip of the snout to the tip of the tail) with a metallic ruler (to the nearest $1 \mathrm{~mm}$ ) and body mass with a pesola spring scale (to the nearest $0.01 \mathrm{~g}$ ). To avoid confounding effects, we measured individuals with empty stomachs. Amphisbaenians usually expulsed most gastrointestinal contents when handled, but we also compressed gently their vents to force the expulsion of feces. The residuals of an ordinary least squares linear regression of log-transformed mass against logtransformed total length $\left(r=0.97, F_{1,38}=645.37, P<0.0001\right)$ were used as a body condition index. It has been argued that such residuals provide the cleanest way to separate the effects of condition from the effects of body size (Bonnet and Naulleau, 1994; Jakob et al., 1996; see reviews in Green, 2000; Schulte-Hostedde et al., 2005). Body condition indexes are used as proxies of health state in many animals (e.g. Schulte-Hostedde et al., 2001; Amo et al., 2006, 2007; Wikelski and Cooke, 2006; Hickman and Swan, 2010; Brischoux et al., 2012). 


\subsection{Soil characteristics}

Sampling sites were classified according to the presence/absence of seabird influence as a) sites close to dense nesting colonies during most years and having recent evident signs of seagull activities on the soil surface (drops, feathers, etc.), or b).sites relatively far ( $>80 \mathrm{~m}$ ) from the nesting or roosting places and with no evidence of seagull activities on the soil surface. Also, we classified sites according to the anthropogenic influence on the soil indicated by the presence/absence in the soil of rests of anthropogenic materials (tiles, bricks, glass, plastic, etc.) or natural materials removed and brought to the surface by men (i.e. alteration of the soil horizons).

We subsequently measured 'soil compaction' at five random points immediately close to the rock where an amphisbaenian was located, and calculated an average value for each site. We used a hand penetrometer (Eijkelkamp Co., Em Giesbeek, The Netherlands) that was pushed vertically into the ground at a slow, steady speed (Herrick and Jones, 2002).

Subsequently, we took a bulked soil sample (around $300 \mathrm{~g}$ ) between the surface and 10 cm depth (or less if the soil was less deep), coinciding with the soil layers used by amphisbaenians (pers. obs.). In the laboratory, soil samples were air-dried, crushed and sieved (< $2 \mathrm{~mm}$ ). Particles between 2 to $60 \mathrm{~mm}$ were weighed to calculate the percentage of 'gravel' in the sample. Thereafter, we used wet sieving to separate the sand fractions ('coarse sand': $2-0.2 \mathrm{~mm}$, and 'fine sand': 0.2-0.05 mm). The percentage of 'silt' $(0.05-0.002 \mathrm{~mm})$ and 'clay' $(<0.002$ $\mathrm{mm}$ ) in the fine earth was determined by using the Bouyoucos hydrometer method (for details of physical analyses see Dane and Topp, 2002)

We also used these soil samples to analyze chemical characteristics. Soil 'total inorganic carbonates' (TIC) were measured using a pressure-calcimeter. Organic carbon (C) was determined using a modified Walkley and Black method, and total organic nitrogen $(\mathrm{N})$ using a Kjeldahl digestion and distillation-titration of the produced ammonium. Available phosphorus (P) was extracted using sodium bicarbonate (0.5M, pH 8.5), and measured by visible spectrophotometry using ammonium molybdate and ascorbic acid. ' $\mathrm{pH}$ ' was measured with a combined electrode in soil paste with water or $\mathrm{KCl}$ (1:2.5). Electrical conductivity' (EC) was measured electrometrically in aqueous extracts (1:5 soil:water). In these extracts, soluble ions 
$\left(\mathrm{Na}^{+}, \mathrm{K}^{+}, \mathrm{Ca}^{2+}, \mathrm{Mg}^{2+}, \mathrm{Cl}^{-}, \mathrm{NO}_{3}{ }^{-}, \mathrm{NH}_{4}{ }^{+}\right.$and $\mathrm{SO}_{4}{ }^{2-}$ ) were determined. $\mathrm{Na}^{+}$and $\mathrm{K}^{+}$were measured by flame photometry, $\mathrm{Ca}^{2+}$ and $\mathrm{Mg}^{2+}$ by atomic absorption spectroscopy, $\mathrm{Cl}^{-}$by titration with $\mathrm{AgNO}_{3}$, and $\mathrm{NO}_{3}{ }^{-}, \mathrm{NH}_{4}{ }^{+}$and $\mathrm{SO}_{4}{ }^{2-}$ by visible spectrophotometry. The availability of nine heavymetal micronutrients (Cd, Co, Cr, $\mathrm{Cu}, \mathrm{Fe}, \mathrm{Mn}, \mathrm{Ni}, \mathrm{Pb}$ and $\mathrm{Zn}$ ) was determined using an ICP-OES device, after extraction with a neutral 0.05 M-EDTA solution (for details of chemical analyses see Sparks, 1996).

\subsection{Data analyses}

Given the high amphisbaenian density (Martín et al., 2011a,c), and because we avoided sampling the same area twice, the probability of repeated sampling of the same individual was very low. We therefore treated all observations as independent. To test for overall differences between sites with presence/absence of seagull influence on soil properties, we used a multivariate analysis of variance (MANOVA) (Sokal and Rohlf, 1995). After rejecting the multivariate null hypotheses we performed univariate ANOVAs to locate which soil characteristics explained the significant multivariate differences found in the previous MANOVA (Scheiner, 2001; García, 2004). To control Type I error inflation, we applied a FDR (False Discovery Rate) tablewise correction (see García, 2003, 2004). For other comparisons we used ANOVAs and simple correlations (Sokal and Rohlf, 1995).

\section{Results}

\subsection{Body condition}

There were not overall significant differences in body condition of amphisbaenians between sexes (males: $-0.02 \pm 0.04$; females: $0.02 \pm 0.04$; Two-way ANOVA, $F_{1,34}=0.01, P=$ 0.99) nor among islands (Isabel: $-0.01 \pm 0.04$; Rey: $0.05 \pm 0.04$; Congreso: $-0.06 \pm 0.05$; $F_{2,34}=$ $0.97, P=0.39)$ and the interaction was not significant $\left(F_{2,34}=0.13, P=0.88\right)$. 


\subsection{Soil salinization}

Amphisbaenians typically avoided using highly to extremely saline soils enriched in salt of marine origin (i.e. dominated by $\mathrm{Na}$ and $\mathrm{Cl}$ ) with high electrical conductivity. However, the few amphisbaenians that were found in soils with higher values of electrical conductivity (i.e. more saline) had significantly lower body conditions than amphisbaenians that live in less saline soils ( $\mathrm{r}=-0.39, F_{1,38}=6.95, P=0.012$ ) (Fig. 1 ). On the other hand, we found a significant negative correlation between soil $\mathrm{pH}$ and soil electrical conductivity $\left(\mathrm{r}=-0.52, F_{1,38}=14.34, P=\right.$ $0.0005)$.

\subsection{Seagull influence on soils}

The presence of nesting colonies of gulls affected significantly through the feces of gulls to the chemical properties of the soil (MANOVA: Wilks' $\lambda=0.085, F_{24,15}=6.68, P=0.0002$ ) (Table 1). Univariate ANOVAs showed that soil samples at points with influence of seagulls presented significantly more acidic $\mathrm{pH}$, higher levels of total $\mathrm{C}$ and $\mathrm{N}$ and much higher available $\mathrm{P}(4 \mathrm{x})$ with respect to soils having negligible inputs of seabird products. Seabird influenced soils had also significantly higher levels of overall salinity $(1.5 \mathrm{x})$, but with different salt composition that sites salinized by sea salts. In seabird-salinized sites dominant ions were $\mathrm{NO}_{3}{ }^{-}$(4.5 times higher than in non-affected soils), $\mathrm{NH}_{4}^{+}(3.5 \mathrm{x})$, and $\mathrm{K}^{+}(2.5 \mathrm{x})$ while typical sea ions $\left(\mathrm{Cl}^{-}\right.$and $\left.\mathrm{Na}^{+}\right)$ were increased only by a 1.6 factor. On the contrary, soil inorganic carbonate reserve was significantly reduced (by 60\%) in highly seabird influenced sites, as were also soluble $\mathrm{Ca}^{++}$ levels. Additionally, we found higher available concentration of most of the measured heavy metals (Table 1). This increase was particularly relevant for several micronutrients (Co, Fe, Mn, and $\mathrm{Zn}$, from 2.0 to $4.5 \mathrm{x}$ ) and for some toxic metals (Cd, Ni or Cr, from 1.5 to 2.0x). $\mathrm{Pb}$ had an opposite tendency; it was about 50\% lower in seabird affected soils, mainly because $\mathrm{Pb}$ is more abundant in the soils of the inhabited Isabel island (see below). Therefore, the presence of seagulls resulted in highly eutrophicated (mainly in available $\mathrm{N}$ and $\mathrm{P}$ ) and nitrate-enriched-saline ornithogenic soils, and with higher heavy metal availability, except for $\mathrm{Pb}$.

Nevertheless, the body condition of amphisbaenians in soils with influence of gulls was not significantly different from locations where there was no seagull influence $(-0.004 \pm 0.036$ 
vs. $+0.005 \pm 0.041$ respectively; ANOVA: $\left.F_{1,38}=0.02, P=0.88\right)$. Therefore, seagull influence on soil chemical properties did not appear to be relevant in determining the body condition of amphisbaenians.

\subsection{Anthropogenic disturbance of soil characteristics}

Amphisbaenians found in disturbed soils, with signs of anthropogenic activities, had a significantly lower body condition than those found in unaltered natural soils (ANOVA: $F_{1,38}=$ 16.45, $P=0.0002$ ) (Fig. 2). This relationship could be explained because anthropogenic disturbed soils had significantly higher contents of gravel than unaltered soils $(43.8 \pm 0.9 \%$ vs. $34.1 \pm 1.1$ $\%$; ANOVA: $\left.F_{1,38}=5.07, P=0.03\right)$. In addition to natural stones, this gravel frequently consisted of remains of anthropogenic activities (e.g. bricks, tiles, or artificially crushed rock or soil deposits of removed "rubble"). In contrast, there were not significant differences between anthropogenic disturbed and natural soils in contents of sand, silt or clay $\left(F_{1,38}<1.23, P>0.27\right.$ in all cases). Soils were significantly more compact when they had more gravel $\left(\mathrm{r}=0.39, F_{1,38}=\right.$ 6.89, $P=0.012$ ), and the amphisbaenians that occupied more compact soils, which are more difficult to excavate, had significantly lower body conditions ( $\mathrm{r}=-0.37, F_{1,38}=6.00, P=0.019$ ) (Fig. 3).

On the other hand, concentrations of lead $(\mathrm{Pb})$ in the soils of the inhabited Isabel island $(30.1 \pm 2.8 \mathrm{mg} / \mathrm{kg}$ soil) were two or three times significantly higher than in the other two uninhabited islands (Rey: $16.2 \pm 2.8 \mathrm{mg} / \mathrm{kg}$ soil; Congreso: $10.0 \pm 3.4 \mathrm{mg} / \mathrm{kg}$ soil; $F_{2,37}=11.66, P$ $=0.00012$; Tukey's tests $P<0.004$ in both cases), which did not differ $(P=0.34)$. However, there were not significant differences in $\mathrm{Pb}$ concentration between physically altered and unaltered soils within Isabel island $(29.3 \pm 5.6 \mathrm{mg} / \mathrm{kg}$ soil vs. $31.3 \pm 6.9 \mathrm{mg} / \mathrm{kg}$ soil; MannWhitney's U-test: $U=21.00, Z=0.71, n=15, P=0.48)$, suggesting that lead contamination affected to all the soils of the inhabited island. Nevertheless, amphisbaenian body condition was not significantly related to $\mathrm{Pb}$ concentration $\left(\mathrm{r}=0.14, F_{1,38}=0.74, P=0.40\right)$. 


\section{Discussion}

We have found that body condition of fossorial amphisbaenians T. wiegmanni varied along some chemical and disturbance soil gradients. Our results suggest that anthropogenic disturbances can be more important than most of naturally induced changes in soil properties. With respect to natural alterations, a strong marine influence (either by direct salt spray deposition or derived from ulterior transport and accumulation) seems to be more harmful to amphisbaenians than soil chemical changes derived from seabird influence. With respect to anthropogenic influences, mechanical disturbance and compaction of the soil affected negatively to body condition of amphisbaenians. In contrast, the increase in organic matter and pollutants in the soil, either because of the seagull or anthropogenic influence, did not seem to affect body condition of amphisbaenians.

\subsection{Salinization of the soil}

Amphisbaenians that used soils more enriched in salt of marine origin (i.e. dominated by $\mathrm{Na}$ and $\mathrm{Cl}$ ), with high electrical conductivity, had a lower body condition. Soil water osmotic potential is inversely related to soil salinity (Bresler et al., 1982), which implies low soil water availability in saline soils. This may cause serious osmoregulation problems to animals (Shoemaker and Nagy, 1977), including osmotic dehydratation of tissues and intoxication by the excess of some soluble ions (e.g. $\mathrm{Na}, \mathrm{Cl}$ ). Thus, for example, even sea snakes that are adapted to living in salt water have lower body condition during periods of high oceanic salinity (Brischoux et al., 2012). In addition, soil salinity restricts the abundance and diversity of vegetation and invertebrate prey of amphisbaenians (García et al., 1993; McKenzie et al., 2003).

Interestingly, although amphisbaenians have no obvious adaptations to saline ambients, $T$. wiegmanni and other species have an urinary bladder (Gans, 1978). This is a water storage structure from which resorption can occur in times of water stress, and may also function in osmoregulation when water resorption is accompanied by ion transport (Shoemaker and Nagy, 1977; Beuchat et al., 1986; Davis and DeNardo, 2007). This might allow amphisbaenians to use xeric saline soils to a higher extent than expected. However, our results suggest that this may be costly because increased soil salinity leads to lower body condition. 


\subsection{Seabird influences}

Out results confirmed that seabird products induce deep soil chemical modifications (García et al., 2002a,b, 2007b). Several of these changed soil parameters are critical for plant and soil fauna conditions, since extreme values represent strong ecological filters, which drastically reduce species richness and individual performance because they should invest a large amount of energy in maintaining homeostasis (García et al., 2002a,b). However, there is a lack of effect of seagulls-induced transformations of the soil on the condition of amphisbaenians. It remains to be analyzed whether toxic heavy metals are being incorporated into amphisbaenians tissues through the trophic chain, and which could be the negative consequences of this potential accumulation (e.g. Márquez-Ferrando et al., 2009).

\subsection{Anthropogenic influences}

The pavement of surfaces and the construction of buildings directly eliminate the habitat available for soil animals (Craul, 1992). But, in addition, even anthropogenic alteration of soil properties in the trails and the areas close to buildings may be a major thread to fossorial animals. Amphisbaenians are still abundant in the seminatural areas close to buildings, below anthropic materials such as bricks, tiles or concrete roof tiles. Anthropic altered soils are, however, more compact and have more gravel, and body condition of amphisbaenians is lower in these most compact soils.

The ability for burrowing and its energetic costs may explain this result. Loose soils are clearly easier for burrowing, which would reduce costs of foraging, mate searching, etc. Soil compaction determine habitat use in this and other amphisbaenians (Martín et al., 1991, 2013a), fossorial skinks (Greenville and Dickman, 2009) or subterranean mammals (e.g. Jackson et al., 2008), which underground movements are energetically more costly in hard soil types (Seymour et al., 1998; Luna and Antinuchi, 2006). In addition, soil compaction can also limit the movements and reduce the availability of soil invertebrate prey (Whalley et al., 1995).

Chemical properties may also be altered by men activities. In the inhabited island of Isabel, soils had on average two to three times greater amounts of $\mathrm{Pb}$ than in the other two 
islands. Contamination by lead can come from water dissolution of old lead pipes, paint chips from buildings, or from incineration of garbage that contain lead (Markus and McBratney, 2000). Exposure to lead may cause adverse effects to human health and the environment (Carrington and Bolger, 1992). However, we have not found an effect of lead on body condition of amphisbaenians, which may be explained by the relatively low levels of lead contamination (i.e. only $10 \%$ of the Isabel values exceed allowed maximum for agricultural soils; L.V. García unpubl. data). Nevertheless, in urban areas in the mainland the lead levels could be much greater and have greater effects on amphisbaenians.

\subsection{Implications for conservation and management of fossorial animals}

Our study indicates that both natural and anthropic alterations of the soil may affect body condition of $T$. wiegmanni amphisbaenians, and thus probably their fitness and the "health" of the populations. Nevertheless, future studies should examine the relevance of the observed low body condition indexes on reproductive output and survival of amphisbaenians. Also,, our study may suffer from some limitations because we did not explore seasonal variation in body condition. We selected a study period with typical spring weather conditions, which coincided with maximum activity of amphisbaenians. However, extreme climatic conditions (e.g. years with lack of rains) might result in different effects of alterations of the soil on body condition. The question that arises is to what extent improved management practices may help to mitigate negative consequences of soil alteration on amphisbaenians.

On the one hand, natural modifications of the soil (i.e. salinization and seagull influence) seem difficult and too expensive to control with small scale management techniques. Amphisbaenians avoid using saline soils (Martín et al., 2013a), but these soils occupy small surface areas in comparison with other more favorable types of soils (García, 2005). Moreover saline soils are of natural origin in our study area and have peculiar ecological characteristics that should also be preserved (García, 2005). Also, seagulls, including one threatened species (Audouin's gull), are naturally nesting here and do not seem to affect amphisbaenians. Nevertheless, an excess of the common yellow legged gulls population is currently subjected to control plans to avoid detrimental effects on soil and vegetation (García et al., 2002a,b). 
With respect to the anthropogenic effects, mechanical soil disturbance may probably explain the absence of amphisbaenians in areas where the soil is more altered by men (Martín et al., 2011a). This might be mitigated by controlling the deposition of building materials and other residues, and avoiding increased compaction of the soil with heavy machinery. Restoration plans of altered soils and associated vegetation might be made if the potential alteration sources can be eliminated. Also, given the low dispersal rates of subterranean animals, a natural recolonization of restored areas may not be expected in a short time, and a possible posterior reintroduction of amphisbaenians and other soil fauna might be reconsidered. Finally, our study emphasizes the need for periodic surveys to collect baseline data on the densities and health state of the little known fossorial herpetofauna in order to prevent future conservation problems before it was too late to solve them.

\section{Acknowledgements}

We thank Johannes Müller and an anonymous reviewer for helpful comments. The field station of the "Refugio Nacional de Caza de las Islas Chafarinas" provided logistical support. We thank Javier Díaz, Gonzalo Martínez, Ángel Sanz, Francisco López, Alfredo Ruiz and Javier Zapata for friendship and help in the Islands. Legal authorization and financial support was

provided by the 'Organismo Autónomo de Parques Nacionales', with additional financial support from a Ministerio de Ciencia e Innovación project (CGL2011-24150/BOS) and from the Regional Government of Andalusia project BIOGEOBIRD (P09-RNM-4987) and FEDER funds.

\section{References}

Amo, L., López, P., Martín, J., 2006. Nature-based tourism as a form of predation risk affects body condition and health state of Podarcis muralis lizards. Biol. Cons. 131, 402-409.

Amo, L., López, P., Martín, J., 2007. Habitat deterioration affects body condition of lizards: a behavioral approach with Iberolacerta cyreni lizards inhabiting ski resorts. Biol. Cons. 135, 77-85.

Beuchat, C.A., Vleck, D., Braun, E.J., 1986. Role of the urinary bladder in osmotic regulation of neonatal lizards. Phys. Zool. 59, 539-551. 
Böhm, M., Collen, B., Baillie, J.E.M., Bowles, P., Chanson, J., et al., 2013. The conservation status of the world's reptiles. Biol. Cons. 157, 372-385.

Bonnet, X., Naulleau, G., 1994. Utilisation d'un indice de condition corporelle (BCI) pour l'étude de la reproduction chez les serpents. Compt. Rend. Acad. Sci. - Ser. II Biol. 317, 34-41.

Bons, J., Geniez, P., 1996. Amphibians and Reptiles of Morocco. Asociación Herpetológica Española, Barcelona, Spain.

Bresler, E., McNeal, B.L., Carter, D.L., 1982. Saline and Sodic Soils: Principles-DynamicsModelling. Springer-Verlag, New York, USA.

Brischoux, F., Rolland, V., Bonnet, X., Caillaud, M., Shine, R., 2012. Effects of oceanic salinity on body condition in sea snakes. Integr. Comp. Biol. 52, 235-244.

Carrington, C.D., Bolger, P.M., 1992. An assessment of the hazards of lead in food. Regul. Toxicol. Pharmacol. 16, 265-272.

Civantos, E., Martín, J., López, P., 2003. Fossorial life constrains microhabitat selection of the amphisbaenian Trogonophis wiegmanni. Can. J. Zool. 81, 1839-1844.

Clemente, L., García, L.V., Rodríguez, A., 1999. Los suelos de la Isla del Congreso (Chafarinas). In: Pallí-Buxó, L., Roque-Pau, C. (Eds), Avances en el Estudio del Cuaternario Español. Actas de la X Reunión Nacional de Cuaternario, Gerona, Spain, pp. 201-206.

Copley, I., 2000. Ecology goes underground. Nature 406, 452-454.

Craul, P.J., 1992. Urban Soil in Landscape Design. John Wiley \& Sons, New York.

Dane, J.H., Topp, G.C. (Eds.), 2002. Methods of Soil Analysis. Part 4. Physical Methods. Soil Science Society of America and American Society of Agronomy. Madison, Wisconsin, USA. Davis, J.R., DeNardo, D.F., 2007. The urinary bladder as a physiological reservoir that moderates dehydration in a large desert lizard, the Gila monster Heloderma suspectum. J. Exp. Biol. 210, 1472-1480.

Decaens, T., Jimenez, J.J., Gioia, C., Measey, G.J., Lavelle, P., 2006. The values of soil animals for conservation biology. Eur. J. Soil Biol. 42, S23-S38.

Dregne, H.E., 1976. Soils of Arid Regions. Developments in soil science 6. Elsevier Science, Amsterdam, The Neatherlands.

Effland, W.R., Pouyat, R.V., 1997. The genesis, classification, and mapping of soils in urban areas. Urban Ecosyst. 1, 217-228. 
Gans, C., 1978. The characteristics and affinities of the Amphisbaenia. Trans. Zool. Soc. Lond. 34, 347-416.

Gans, C., 2005. Checklist and bibliography of the amphisbaenia of the World. Bull. Am, Mus. Nat. Hist. 280, 1-130.

García, L.V., 2003. Controlling the false discovery rate in ecological research. Trends Ecol. Evol. $8,553-554$.

García, L.V., 2004. Escaping the Bonferroni iron claw in ecological studies. Oikos 105, 657-663. García, L.V., 2005. Suelos de las Islas Chafarinas y sus relaciones ecológicas. Ecosistemas 14, 135-139.

García, L.V., Marañón, T., Moreno, A., Clemente, L., 1993. Aboveground biomass and species richness in a Mediterranean salt marsh. J. Veg. Sci. 4, 417-424

García, L.V., Marañón T., Clemente, L., 2002a. Animal influences on soil properties and plant cover in the Chafarinas Islands (NW Africa). In: Rubio, J.L., Morgan, R.P.C., Asins, S. (Eds.), Man and Soil at the Third Millennium, Vol. 1. Geoforma, Logroño, Spain, pp. 705712.

García, L.V., Marañón, T., Ojeda, F., Clemente, L., Redondo, R., 2002b. Seagull influence on soil properties, chenopod shrub distribution, and leaf nutrient status in semi-arid Mediterranean islands. Oikos 98, 75-86.

García, L.V., Clemente, L., Gutiérrez, E., Jordán, A., 2007a. Factores condicionantes de la diversidad edáfica en las Islas Chafarinas. In: Bellinfante, N., Jordán, A. (Eds.), Tendencias Actuales de la Ciencia del Suelo. Universidad de Sevilla, Sevilla, Spain, pp. 828-833.

García, L.V., Gutiérrez, E., T. Marañón, R. Redondo, Clemente, L., 2007b. Acumulación de metales pesados en el suelo mediada por aves marinas: evidencias derivadas del análisis Isotópico. In: Rodríguez, A., Arbelo, C.D. (Eds.), Control de la Degradación de Suelos y la Desertificación. Universidad de la Laguna, Tenerife, Spain, pp. 255-256.

Green, A.J., 2000. Mass/length residuals: measures of body condition or generation of spurious results? Ecology 82, 1473-1483.

Greenville, A.C., Dickman, C.R., 2009. Factors affecting habitat selection in a specialist fossorial skink. Biol. J. Linn. Soc. 97, 531-544.

Headley, A. D., 1996. Heavy metal concentrations in peat profiles from the high Arctic. Sci. Tot. Environ. 177, 105-111. 
Heino, M., Kaitala, V., 1999. Evolution of resource allocation between growth and reproduction in animals with indeterminate growth. J. Evol. Biol. 12, 423-429.

Herrick, J.E., Jones, T.L., 2002. A dynamic cone penetrometer for measuring soil penetration resistance. Soil Sci. Am. J. 66, 1320-1324.

Hickman, D.L., Swan, M., 2010. Use of a body condition score technique to assess health status in a rat model of polycystic kidney disease. J. Am. Assoc. Lab. Anim. Sci. 49, 155-159.

How, R.A., Shine, R., 1999. Ecological traits and conservation biology of five fossorial `sandswimming' snake species (Simoselaps: Elapidae) in south-western Australia. J. Zool. 249, 269-282.

Jackson, C.R., Lubbe, N.R., Robertson, M.P., Setsaas, T.H., van der Waals, J., Bennett, N.C., 2008. Soil properties and the distribution of the endangered Juliana's golden mole. J. Zool. (Lond.) 274, 13-17.

Jakob, E.M., Marshall, S.D., Uetz, G.W., 1996. Estimating fitness: a comparison of body condition indices. Oikos 77, 61-67.

López, P., Salvador, A., Martín, J., 1998. Soil temperatures, rock selection and the thermal ecology of the amphisbaenian reptile Blanus cinereus. Can. J. Zool. 76, 673-679.

López, P., Civantos, E., Martín, J., 2002. Body temperature regulation in the amphisbaenian Trogonophis wiegmanni. Can. J. Zool. 80, 42-47.

Luna, F., Antinuchi, C.D., 2006. Cost of foraging in the subterranean rodent Ctenomys talarum: effect of soil hardness. Can. J. Zool. 84, 661-667.

Madsen, T., Shine, R., 2002. Short and chubby or long and slim? Food intake, growth and body condition in free-ranging pythons. Austral Ecol. 27, 672-680.

Markus, J., McBratney, A.B., 2000. A review of the contamination of soil with lead. I. Origin, occurrence and chemical form of soil lead. Progr. Environm. Sci. 24, 291-318.

Márquez-Ferrando, R., Santos, X., Pleguezuelos, J.M., Ontiveros, D., 2009. Bioaccumulation of heavy metals in the lizard Psammodromus algirus after a tailing-dam collapse in Aznalcóllar (Southwest Spain). Arch. Environ. Contam. Toxicol. 56, 276-285.

Martín, J., López, P., Salvador, A., 1990. Field body temperatures of the amphisbaenid lizard Blanus cinereus. Amphib.-Rept. 11, 87-96.

Martín, J., López, P., Salvador, A., 1991. Microhabitat selection of the amphisbaenian Blanus cinereus. Copeia 1991, 1142-1146. 
Martín, J., Polo-Cavia, N., Gonzalo, A., López, P., Civantos, E., 2011a. Distribución, abundancia y conservación de la culebrilla mora (Trogonophis wiegmanni) en las Islas Chafarinas. Bol. Asoc. Herp. Esp. 22, 107-112.

Martín, J., Polo-Cavia, N., Gonzalo, A., López, P., Civantos, E., 2011b. Social aggregation behaviour in the North African amphisbaenian Trogonophis wiegmanni. Afr. J. Herp. 60, 171-176.

Martín, J., Polo-Cavia, N., Gonzalo, A., López, P., Civantos, E., 2011c. Structure of a population of the amphisbaenian Trogonophis wiegmanni in North Africa. Herpetologica 67, 250-257.

Martín, J., Polo-Cavia, N., Gonzalo, A., López, P., Civantos, E., 2012. Sexual dimorphism in the North African amphisbaenian Trogonophis wiegmanni. J. Herp. 46, 338-341.

Martín, J., López, P., García, L.V., 2013a. Soil characteristics determine microhabitat selection of the fossorial amphisbaenian Trogonophis wiegmanni. J. Zool. (Lond.) 290, 265-272.

Martín, J., Ortega, J., López, P., Pérez-Cembranos, A., Pérez-Mellado, V., 2013b. Fossorial life does not constrain diet selection in the amphisbaenian Trogonophis wiegmanni. J. Zool. (Lond.) 291, 226-233.

Mateo, J.A., Joger, J., Pleguezuelos, J., Slimani, T., Martínez-Solano, I., 2009. Trogonophis wiegmanni. In: IUCN 2012. IUCN Red List of Threatened Species. Version 2012.2. <www.iucnredlist.org>. Accessed on 24 November 2012.

McKenzie, N.L., Burbidge, A.H., Rolfe, J.K., 2003. Effect of salinity on small, ground-dwelling animals in the Western Australian wheatbelt. Aust. J. Bot. 51, 725-740.

Measey, G.J., 2006. Surveying biodiversity of soil herpetofauna: towards a standard quantitative methodology. Eur. J. Soil Biol. 42, S103-S110.

Measey, G.J., Armstrong, A.J., Hanekom, C., 2009. Subterranean herpetofauna show a decline after 34 years in Ndumu Game Reserve, South Africa. Oryx 43, 284-287.

Otero, X.L., 1998. Effects of nesting yellow-legged gulls (Larus cachinnans Pallas) on the heavy-metal content of soils in the Cies Islands (Galicia, north-west Spain). Marine Pollut. Bull. 36, 267-272.

Papenfuss, T.J., 1982. The ecology and systematics of the amphisbaenian genus Bipes. Occ. Pap. Calif. Acad. Sci. 136, 1-42.

Perrin, N., Sibly, R.M., 1993. Dynamic models of energy allocation and investment. Annu. Rev. Ecol. Syst. 24, 379-410. 
Rengasamy, P., 2006. World salinization with emphasis on Australia. J. Exp. Bot. 57, 10171023.

Scheiner, M.S., 2001. MANOVA: multiple response variables and multispecies interactions. In: Scheiner, M.S., Gurevitch, J. (Eds.), Design and Analysis of Ecological Experiments, second ed. Oxford University Press, New York, pp. 99-115.

Schulte-Hostedde, A.I., Millar, J.S., Hickling, G.J., 2001. Evaluating body condition in small mammals. Can. J. Zool. 79, 1021-1029.

Schulte-Hostedde, A.I., Zinner, B., Millar, J.S., Hickling, G.J., 2005. Restitution of mass-size residuals: validating body condition indices. Ecology 86, 155-163.

Seymour, R.S., Withers, P.C., Weathers, W.W., 1998. Energetics of burrowing, running, and free-living in the Namib desert golden mole (Eremitalpa mamibensis). J. Zool. (Lond.) 244, 107-117.

Shoemaker, V.H., Nagy, K.A., 1977. Osmoregulation in amphibians and reptiles. Annu. Rev. Physiol. 39, 449-471.

Sokal, R.R., Rohlf, F.J., 1995. Biometry. 3rd ed. New York, USA: W.H. Freeman and Co.

Sparks, D.L. (Ed), 1996. Methods of Soil Analysis. Part 3. Chemical Methods. Soil Science Society of America and American Society of Agronomy, Madison, Wisconsin, USA.

Webb, J.K., Shine, R., Branch, W.R.,, Harlow, P.S., 2000. Life underground: food habits and reproductive biology of two amphisbaenian species from South Africa. J. Herp. 34, 510-516.

Whalley, W.R., Dumitru, E., Dexter, A.R., 1995. Biological effects of soil compaction. Soil Tillage Res. 35, 53-68.

Wikelski, M., Cooke, S.J., 2006. Conservation physiology. Trends Ecol. Evol. 21, 38-46.

Wolters, V., 2001. Biodiversity of soil animals and its function. Eur. J. Soil Biol. 37, 221-227.

Zeppel, M.J.B., Murray, B.R., Eamus, D., 2003. Dryland salinity and effects on threatened species. Ecol. Manag. Restor. 4, 53-59. 
Table 1

Seagull influence on chemical properties (mean \pm SE) of soils used by $T$. wiegmanni amphisbaenians. After applying a sharpened FDR correction, the new calculated significance threshold exceeded the uncorrected one. Therefore, the latter (i.e. $P<0.05$ ) was applied, and the significant values marked in bold.

\begin{tabular}{|c|c|c|c|c|c|c|}
\hline \multirow[b]{2}{*}{$\mathrm{pH}_{\mathrm{H} 2 \mathrm{O}(1 / 2.5)}$} & \multicolumn{2}{|c|}{$\begin{array}{l}\text { Without gulls } \\
(n=17)\end{array}$} & \multicolumn{2}{|c|}{$\begin{array}{l}\text { With gulls } \\
(n=23)\end{array}$} & \multirow{2}{*}{$\begin{array}{l}F_{1,38} \\
17.16\end{array}$} & \multirow{2}{*}{$\begin{array}{l}P \\
0.0002\end{array}$} \\
\hline & 8.4 & \pm 0.1 & 7.6 & \pm 0.2 & & \\
\hline $\mathrm{pH}_{\mathrm{KCl}(1 / 2.5)}$ & 7.7 & \pm 0.1 & 7.2 & \pm 0.1 & 8.58 & 0.006 \\
\hline Total inorganic carbonates (\%) & 25.8 & \pm 2.5 & 10.9 & \pm 1.6 & 28.12 & $<0.0001$ \\
\hline Organic C (\%) & 2.3 & \pm 0.2 & 3.7 & \pm 0.3 & 11.35 & 0.0017 \\
\hline $\mathrm{N}_{\text {Kjeldalh }}(\%)$ & 0.2 & \pm 0.0 & 0.5 & \pm 0.0 & 33.40 & $<0.0001$ \\
\hline $\mathrm{P}_{\text {Olsen }}(\mathrm{mg} / \mathrm{kg}$ soil $)$ & 61.5 & \pm 10.4 & 268.1 & \pm 30.2 & 32.34 & $<0.0001$ \\
\hline Electrical conductivity $\left(\mathrm{dS} \mathrm{m}^{-1}\right)$ & 0.4 & \pm 0.1 & 0.6 & \pm 0.1 & 4.68 & 0.037 \\
\hline $\mathrm{Na}^{+}{ }_{1 / 5}(\mathrm{mg} / \mathrm{kg}$ soil $)$ & 146.8 & \pm 27.5 & 232.8 & \pm 17.5 & 7.61 & 0.009 \\
\hline $\mathrm{K}_{1 / 5}^{+}(\mathrm{mg} / \mathrm{kg}$ soil $)$ & 70.9 & \pm 13.9 & 172.4 & \pm 17.8 & 17.94 & 0.00014 \\
\hline $\mathrm{Ca}^{++}{ }_{1 / 5}(\mathrm{mg} / \mathrm{kg}$ soil $)$ & 154.6 & \pm 30.0 & 128.2 & \pm 10.0 & 0.87 & 0.36 \\
\hline $\mathrm{Mg}^{++}{ }_{1 / 5}(\mathrm{mg} / \mathrm{kg}$ soil $)$ & 29.5 & \pm 3.8 & 30.6 & \pm 2.5 & 0.06 & 0.80 \\
\hline $\mathrm{Cl}_{1 / 5}^{-}(\mathrm{mg} / \mathrm{kg}$ soil $)$ & 284.7 & \pm 75.6 & 464.2 & \pm 51.6 & 4.13 & 0.049 \\
\hline $\mathrm{NO}_{3}{ }^{-}$(mg/kg soil) & 8.3 & \pm 2.3 & 37.0 & \pm 2.9 & 54.66 & $<0.0001$ \\
\hline $\mathrm{NH}_{4}^{+}(\mathrm{mg} / \mathrm{kg}$ soil $)$ & 21.2 & \pm 1.9 & 69.2 & \pm 14.4 & 8.11 & 0.007 \\
\hline $\mathrm{SO}_{4}={ }_{1 / 5}(\mathrm{mg} / \mathrm{kg}$ soil $)$ & 173.3 & \pm 111.7 & 130.4 & \pm 24.1 & 0.18 & 0.67 \\
\hline Cd (mg/kg soil) & 0.1 & \pm 0.0 & 0.2 & \pm 0.0 & 31.21 & $<0.0001$ \\
\hline Co (mg/kg soil) & 0.2 & \pm 0.0 & 0.4 & \pm 0.0 & 29.28 & $<0.0001$ \\
\hline Cr (mg/kg soil) & 0.1 & \pm 0.0 & 0.2 & \pm 0.0 & 2.26 & 0.14 \\
\hline Cu (mg/kg soil) & 2.8 & \pm 0.3 & 4.3 & \pm 0.6 & 4.50 & 0.04 \\
\hline Fe (mg/kg soil) & 23.8 & \pm 2.8 & 89.8 & \pm 18.4 & 9.28 & 0.004 \\
\hline Mn (mg/kg soil) & 21.6 & \pm 5.2 & 93.5 & \pm 12.5 & 22.16 & $<0.0001$ \\
\hline Ni (mg/kg soil) & 0.4 & \pm 0.1 & 0.6 & \pm 0.1 & 4.71 & 0.036 \\
\hline Pb (mg/kg soil) & 27.4 & \pm 4.1 & 14.3 & \pm 1.2 & 11.82 & 0.0015 \\
\hline Zn (mg/kg soil) & 16.4 & \pm 1.8 & 42.2 & \pm 6.5 & 11.05 & 0.002 \\
\hline
\end{tabular}


Fig. 1. Relationship between soil electrical conductivity (i.e. soils with higher values are more saline) and body condition of amphisbaenians found in those soils.

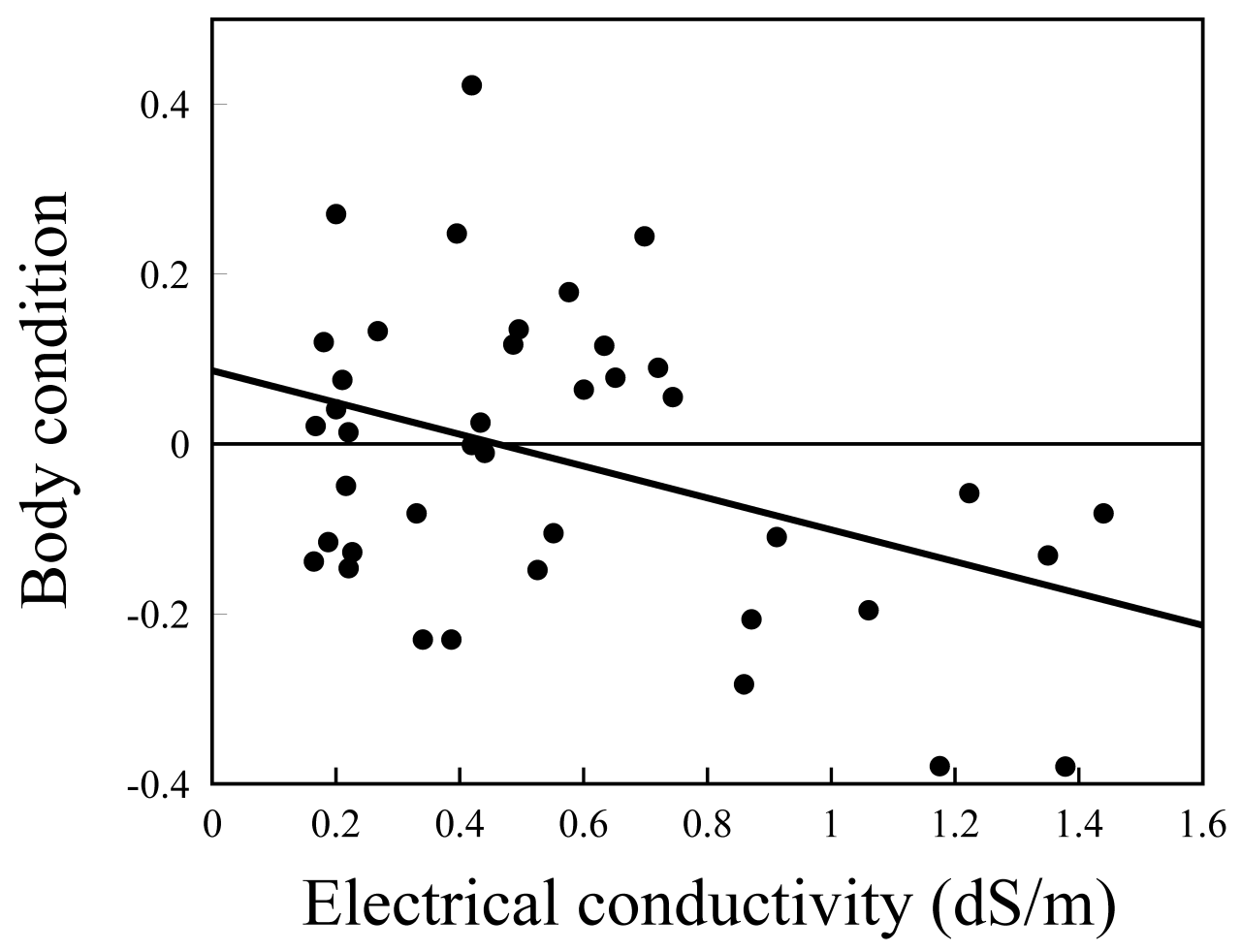


Fig. 2. Comparison of body condition (mean; SE) of amphisbaenians found in natural soils or disturbed soils with signs of anthropogenic activities.

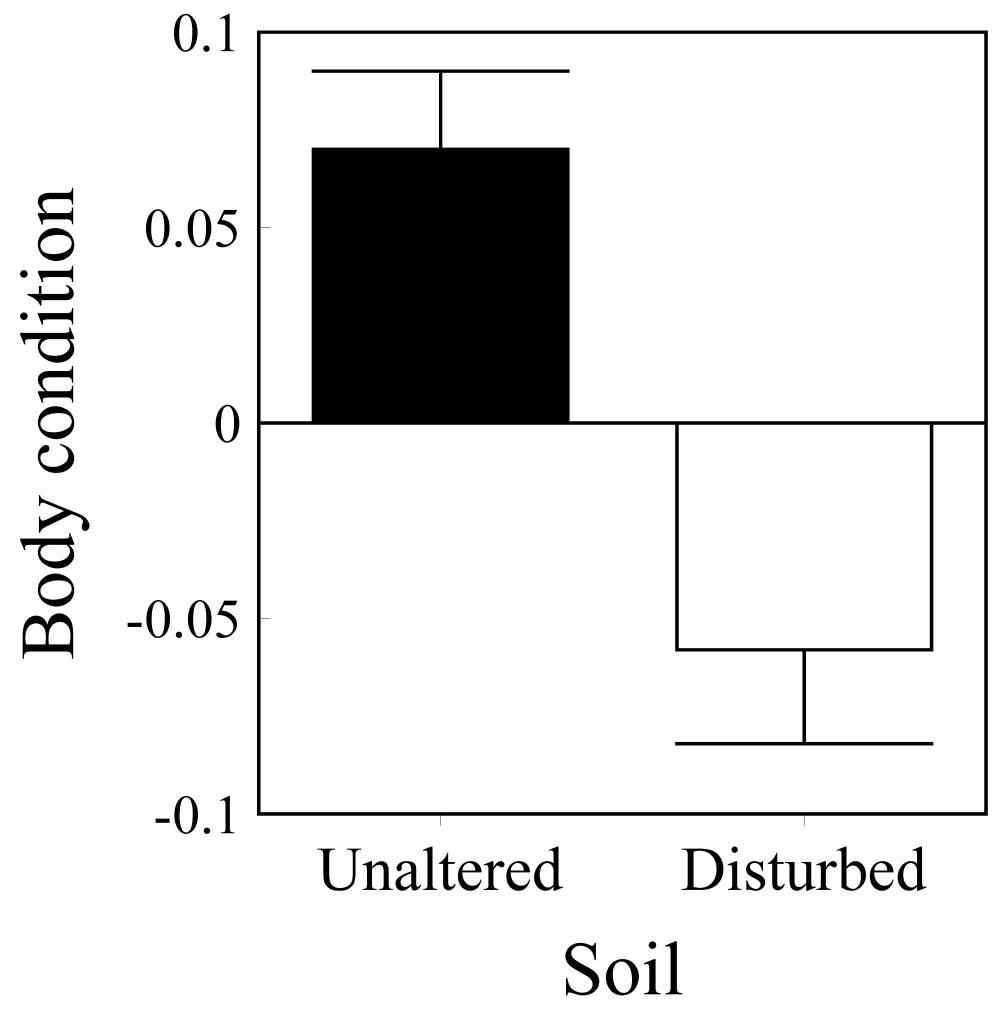


Fig. 3. Relationship between soil compaction and body condition of amphisbaenians found in those soils.

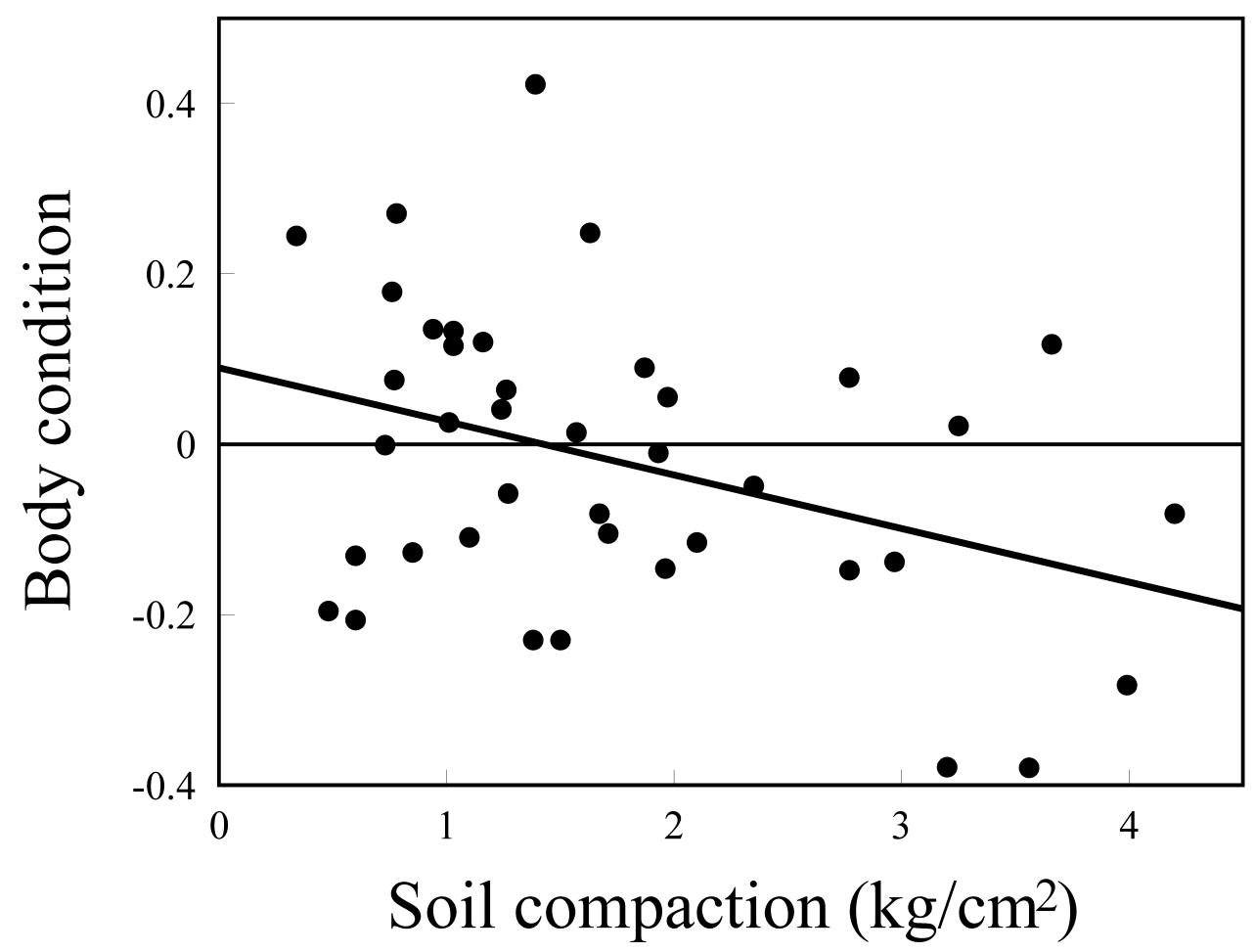

